\title{
Laboratory Hydro-mechanical Characterisation of Boom Clay at Essen and Mol
}

Y. F. Deng ${ }^{1,2}$, A. M. Tang ${ }^{2}$, Y. J. Cui ${ }^{2}$, X. P. Nguyen ${ }^{2}$, X. L. Li ${ }^{3}$, L. Wouters ${ }^{4}$

${ }^{1}$ Southeast University, Institute of Geotechnical Engineering, Transportation College, Nanjing, China (noden@163.com)

${ }^{2}$ Ecole des Ponts ParisTech, Navier/CERMES, Marne-la-Vallée, France (yujun.cui@enpc.fr)

${ }^{3}$ Euridice Group, c/o SCK/CEN, Mol, Belgium (xli@ sckcen.be)

${ }^{4}$ ONDRAF/NIRAS, Belgium (1.wouters@nirond.be)

\section{Corresponding author}

Prof. Yu-Jun CUI

Ecole des Ponts ParisTech, UR Navier/CERMES

6-8 av. Blaise Pascal, Cité Descartes, Champs-sur-Marne

F-77455 MARNE-LA-VALLEE CEDEX 2

France

Email: yujun.cui@enpc.fr

Tel: +33164153550

Fax: +33164153562 


\begin{abstract}
Boom clay has been selected as a potential host rock formation for the geological disposal of radioactive waste in Belgium. In the present work, the hydro-mechanical behaviour of Boom clay samples from the borehole Essen-1 at a depth of 220 - $260 \mathrm{~m}$ and from HADES that is the underground rock laboratory at Mol in Belgium, at 223-m depth was investigated in the laboratory by performing low pressure oedometer tests (vertical effective stress ranging from 0.05 to $3.2 \mathrm{MPa}$ ), high pressure oedometer tests (vertical effective stress ranging from 0.125 to $32 \mathrm{MPa}$ ), isotropic consolidation tests (confining effective stress ranging from the in-situ stress to $20 \mathrm{MPa}$ ) and triaxial shear tests. It has been observed that the mineralogy, geotechnical properties and hydro-mechanical behaviour of Boom clay from Essen at 227-m, 240-m and 248-m depths are similar to that of Boom clay from Mol. As in the case of Boom clay at Mol, the failure envelope of Boom clay at Essen in the $p^{\prime}-q$ plane is not linear. The slope of the portion beyond the pre-consolidation stress of Boom clay from Essen is almost the same as that from Mol, suggesting a similar internal friction angle of about $13^{\circ}$. The compression curves (void index $I_{v}$ versus logarithm of vertical stress) beyond the pre-consolidation stress are the same for both samples from Mol and Essen, and situated between the intrinsic compression line (ICL) and the sedimentation compression line (SCL). The yield stress determined from oedometer tests seems to be stress-path dependent and lower than the pre-consolidation stress. Thus determining the over-consolidation ratio (OCR) using the yield stress value would lead to an incorrect estimate. From a practical point view, the laboratory test results from Essen and their comparison with those from Mol provide important information regarding the transferability of knowledge on Boom clay at different sites, taking into account the fact that most investigations have been carried out on Boom clay at Mol.
\end{abstract}

Keywords: Boom clay; hydro-mechanical behaviour; compression; shear strength; void index; pre-consolidation stress, yield stress. 


\section{Introduction}

Boom clay, a Tertiary clay formation has been selected as a potential host rock for the disposal of High Level and Long-lived radioactive Waste (HLLW) in Belgium. In order to study the feasibility of such disposal, an underground facility called HADES (High-Activity Disposal Experimental Site) excavated at 223-m depth close to the city of Mol was constructed in 1980. Since then, many experimental investigations have been conducted, under laboratory and field conditions to understand the Hydro-Mechanical (HM) behaviour of the clay around the excavations (Bernier et al., 2007; Delage et al. 2007; Cui et al., 2009).

In the Belgian program for nuclear waste management, the Essen site located in the north-east of Belgium, about $60 \mathrm{~km}$ far from Mol (Figure 1) has been considered as an alternative site (De Craen et al., 2006). A borehole (Essen-1) was drilled in order to make fundamental geological, hydraulic, geochemical investigations of the Boom clay formation situated at depths between $153 \mathrm{~m}$ and $280 \mathrm{~m}$ (Figure 2) to allow assessment of this site. As shown in Figure 2, the Boom formation is composed of the following four members: Transition, Putte, Terhagen and Belsele-Waas members. Figure 3 (Wemaere et al., 2008) presents the hydro-geological crosssection of Boom clay formation, where the respective positions of Mol site and Essen site are also indicated. It is observed that the Boom clay formation was inclined upward from Mol to Essen. The underground water flows within two aquifers, the Neogene aquifer above the Boom clay formation and the Rupelian aquifer below the formation, also in the direction from Mol to Essen. This flow direction is likely related to the sea situated in the west. De Craen et al. (2006) found that the pore water of Boom clay at Essen is characterised by a relatively high salinity, ranging from $1470 \mathrm{mg} / \mathrm{l}$ to $7249 \mathrm{mg} / \mathrm{l}$. The large range in salinity reflects enrichment in salinity from the top to the bottom of the clay. In addition, the Boom clay pore water at Essen is clearly different from that at the Mol site in terms of type, salinity and vertical variations in chemical composition.

In the present work, five cores from different depths at Essen and one core from 223-m depth at Mol were investigated in hydro-mechanical experiments. The results will provide useful information regarding the transferability of knowledge on Boom clay at different sites, taking into account the fact that most investigations have been carried out at the Mol site.

\section{Boom clay studied}

The sample materials studied were taken from the borehole drilled at Essen where the Boom clay formation is composed of four horizons: Transition zone $(153-200 \mathrm{~m})$, Putte $(200-238$ $\mathrm{m})$, Terhagen $(238-260 \mathrm{~m})$ and Belsele-Waas $(260-280 \mathrm{~m})$ (see Figure 2 after Labat et al., 2008). Five cores (1-m long and $100-\mathrm{mm}$ in diameter) were sealed in plastic tubes and transported to the laboratory for testing. A core taken from HADES at Mol at 223-m depth was tested for comparison. The detail of these cores is shown in Table 1.

For Boom clay at Essen, two cores were taken from the Putte member (Ess75 and Ess83) and three cores from the Terhagen member (Ess96, Ess104 and Ess112). The geotechnical properties of these cores are similar: specific gravity, $G_{s}=2.64-2.68$; liquid limit, $w_{L}=62-$ 78\%; plastic limit, $w_{P}=25-33 \%$; plastic index, $I_{P}=36-45$. The water content $(w)$ ranges from 26.5 to $29.7 \%$; and the void ratio $(e)$ from 0.700 to 0.785 . The adsorption capacity characterised by the Methylene Blue Value (MB) was also similar: $\mathrm{MB}=6.20-6.83$. Note that $\mathrm{MB}$ is usually used to determine the specific surface area of soils. The carbonate content of the 
core Ess $104(4.36 \%)$ is significantly higher than that of other cores (lower than $1 \%)$. Note that the carbonate content for Ess 112 is also relatively high: $2.64 \%$.

After Francois et al. (2009), the main parameters of the Boom clay at Mol e.g. $G_{s}, w_{L}, w_{p}, I_{p}$ and $w$ are similar to those of the Boom clay at Essen. The void ratio $e$ ranges from 0.49 to 0.67 , significantly lower than that of Boom clay at Essen; the MB is much lower also but the carbonate content, between 5.9 and $8.3 \%$, is significantly higher. These differences suggest that the Boom clay at Mol is denser, more carbonated and less active from a mineralogical point of view.

Table 2 presents the mineralogical composition of the clay samples and Table 3 presents the mineralogy of the clay fractions (particles $<2 \mu \mathrm{m}$ ). It is observed from Table 2 that the main minerals of Boom clay at Essen and Mol are quartz, illite/mica and kaolinite; the mineralogical composition of Ess83, Ess96, Ess104 and Mol are almost similar while the quartz content of Ess 75 and the kaolinite fraction of Ess 112 are relatively lower. The mineralogical composition of clay portion (fraction $<2 \mu \mathrm{m}$ ) is similar for Boom clay at Essen and at Mol except for Ess 112 with a significantly higher smectite content, $50 \%$ (Table 3 ).

The particle size distribution curves are shown in Figure 4. The curves of Ess83 and Ess96 are close to that of Mol (after Coll, 2005), showing a clay content $(<2 \mu \mathrm{m})$ of $57-60 \%$; the curves of Ess75 and Ess104 are slightly below the three curves above, showing a clay content of 4350\%; The core Ess 112 presents significantly larger particles and a lower clay content (about $40 \%)$.

Note that with a larger MB, Boom clay at Essen is expected to contain more active minerals such as smectite and mixed layer clays i.e. illite/smectite; but data in Table 3 does not support this point. Examination of the grain size distribution curve shows that it is probably the combined effect of clay content and clay activity that leads to a larger MB for Boom clay at Essen. For instance, Ess 112 has the highest content of smectite and interstratified illite/smectite (60\% in total, Table 3), but also the lowest clay fraction (40\%, Figure 4).

\section{Experimental techniques}

Both low-pressure (0.05-3.2 $\mathrm{MPa}$ ) and high-pressure (0.1-32MPa) oedometer tests were performed on the six Boom clay cores (five from Essen and one from Mol). The soil samples were prepared by wire saw trimming to get $50 \mathrm{~mm}$ in diameter and $20 \mathrm{~mm}$ in height. The degree of saturation of the samples prepared was found to be close or equal to unity (see Table 1), suggesting that no little desaturation occurred during cores storage and samples preparation. In the following, high pressure oedometer test is named Oedo1 while low pressure test is named Oedo2. Isotropic consolidation and triaxial shear tests were also carried out on samples of $38 \mathrm{~mm}$ in diameter and $76 \mathrm{~mm}$ high, prepared also by wire saw trimming. Note that these tests were performed following French standards (AFNOR 1995, 2005a and 2005b). The pore water used is a synthetic solution having the same chemistry as in-situ pore water (see in Cui et $a l ., 2009)$. The vertical displacement was measured using LVDT to an accuracy of $\pm 0.001 \mathrm{~mm}$.

For each test, the specimen was installed in the cell with dry porous stones. Prior to circulation of the synthetic water in the drainage system, an initial pressure equal to the in situ stress was applied. That prevents the soil swelling during saturation which may modify the soil microstructure and as a consequence the soil mechanical properties (Delage et al., 2007). The in situ stress of the soil was estimated using Eq. [1]: 
where $\sigma_{v 0}^{\prime}$ is the in situ effective vertical stress; $\gamma$ is the mean unit weight of the formations above the depth considered, taken equal to $20 \mathrm{kN} / \mathrm{m}^{3}$ following the data of De Craen et al. (2006); $h$ is the depth of the core (see Table 1 ); $u_{0}$ is the in situ pore pressure estimated from the ground water level that is assumed to be at the ground surface. The $\sigma_{v 0}^{\prime}$ values thus determined for Ess75, Ess83, Ess96, Ess104, Ess112 and Mol are 2.20, 2.27, 2.40, 2.48, 2.56 and 2.23MPa, respectively. For a reason of convenience, $\sigma_{v 0}^{\prime}$ in both high pressure Oedometer and low pressure Oedometer was set at 2.40 MPa for all tests.

In isotropic ccompression and triaxial shear tests, the back pressure was applied using a volume/pressure controller; the in situ effective pressure $\sigma_{v 0}^{\prime}$ was set at the respective value calculated above. Owing to the lack of the $K_{0}$ coefficient (coefficient of earth pressure at rest), the horizontal stress was considered as equal to the vertical stress $\left(K_{0}=1.0\right)$. After saturating the soil sample with synthetic water under the in situ stress, the confining pressure and the back pressure were increased step-by-step by keeping constant the effective confining pressure $p$ ' (the difference between the confining pressure and the back pressure, equal to the in situ effective pressure $\sigma_{v 0}^{\prime}$ ), until a back pressure of $1000 \mathrm{kPa}$.

compression tests were performed only on four cores (Ess75, Ess83, Ess96, Ess104) and triaxial shear tests only on three cores (Ess75, Ess83 and Ess96).

\section{Experimental results}

\subsection{Oedometer tests}

Figure 5 presents the loading-unloading-reloading stages and the corresponding changes in vertical displacement in test Ess750edo1. Before the saturation phase, a loading from 0.125 to 2.4 $\mathrm{MPa}$ was applied to reach the in situ stress state. The soil sample was then saturated using synthetic water. The subsequent unloading-reloading stages are: unloading from point A (2.4 $\mathrm{MPa})$ to $\mathrm{B}(0.125 \mathrm{MPa})$; loading to $\mathrm{C}(16 \mathrm{MPa})$; unloading to $\mathrm{D}(0.125 \mathrm{MPa})$; loading to $\mathrm{E}$ (32 $\mathrm{MPa})$ and unloading to $\mathrm{F}(0.125 \mathrm{MPa})$. Common results were obtained in terms of vertical displacements, i.e., compression upon loading and rebounding upon unloading. Note that the French standards, AFNOR (1995, 2005a), were applied as regards the deformation stabilisation: stabilisation is achieved when the displacement rate is lower than $0.01 \mathrm{~mm} / \mathrm{h}$ (corresponding to $1.4 \times 10^{-7} / \mathrm{s}$ in this case).

Figure 6 presents the compression curve (void ratio versus $\sigma_{v}^{\prime}$ ) of test Ess750edo1, together with the compression curve of test Ess75Oedo2 in low pressure oedometer. Note that in test Ess75Oedo2, three initial loading cycles (0.05 MPa to $2.4 \mathrm{MPa}, 2.4 \mathrm{MPa}$ to $0.05 \mathrm{MPa}$, and 0.05 $\mathrm{MPa}$ to $2.4 \mathrm{MPa}$ ) were applied to make good contact between the sample, the porous stone and the cell. That eliminates the effects of possible soil disturbance due to the transport, conservation and sample preparation. The sample was then re-saturated using synthetic water (having chemical composition similar to the in situ pore water). Afterwards, step unloading was performed from point I $(2.4 \mathrm{MPa})$ to point II $(0.05 \mathrm{MPa})$, loading to point III (3.2 $\mathrm{MPa})$, unloading to point IV (0.05 MPa).

The determination of the compressibility parameters from the compression curve of test Ess750edo1 is shown in Figure 7. As the curves obtained do not present a clear elasto-plastic behaviour, a yield stress $\left(\sigma_{y}^{\prime}\right)$ is determined for each loading stage by the Casagrande 
method: $\sigma_{y B-C}^{\prime}, \sigma_{y D-E}^{\prime}$. The compression index $C_{c}$ and the swelling index $C_{s}$ are also determined from the slopes - $\mathrm{d} e / \mathrm{d} \log \sigma_{v}$ of this curve. Note that the yield stress $\left(\sigma_{y}^{\prime}\right)$ is determined from the $e-\log \sigma_{v}$ plot while the pre-consolidation stress $\left(\sigma_{c}^{\prime}\right)$ is defined as the maximum stress applied, following the stress history of the soil.

The compression curves of all the oedometer tests are shown in Figure 8. It can be observed that the loading parts are continuous in the full range from low to high stresses. The slopes of the unloading parts are similar for both low and high pressure oedometer tests. From these results, the compressibility parameters were determined using the method described in Figure 7 for all the six cores. Table 4 shows the values of $C_{c}, C_{s}, \sigma_{\mathrm{y}}$ and $\sigma^{\prime}$ c for each stage. It is observed that $C_{c}$ values from low pressure oedometer tests are lower than that from high pressure oedometer tests. This can be explained by the fact that the maximum pressure in low pressure oedometer tests was limited to $3.2 \mathrm{MPa}$, likely not high enough to evidence the postyield compression behaviour. The $C_{c}$ parameter from high pressure oedometer tests ranges from 0.302 to 0.405 , and the value of Ess 112 is the smallest one. The parameter $C s_{A->B}$ ranges from 0.041 to 0.110 and the smallest one is also for Ess112. $C_{S C->D}, C_{S E->F}, C_{S I->I I}$ and $C_{S I I I->I V}$ are similar for all samples, comprised between 0.076 and 0.165 . Again, the values for Ess 112 have been found to be the lowest ones.

In Table 4 , the yield stress $\sigma_{y}$ determined is also shown. It is observed that the yield stress determined on the two reloading paths $\mathrm{BC}$ (after a pre-loading up to $2.4 \mathrm{MPa}$, point $\mathrm{A}$ ) and $\mathrm{DE}$ (after a pre-loading up to $16 \mathrm{MPa}$, point $\mathrm{C}$ ) are similar (see also Figure 6). For instance, the values of $\sigma_{y B->C}^{\prime}$ and $\sigma_{y D->E}^{\prime}$ of test Ess750edo1 are both 1.4 MPa (see also Figure 7). Actually, the yield stress determined on the reloading paths does not correspond to the pre-consolidation stress because it is significantly lower than the maximum stress that the specimen has been subjected to in the field. This decrease can be explained by the swelling of clay samples during unloading which induces significant changes of clay microstructure.

In this study, the oedometer modulus is analyzed step by step using Eq. [2]:

$E_{\text {Oedo }}=h_{i}\left(d \sigma_{v}^{\prime} / d h\right)$

Where $h_{i}$ is the initial height of the soil sample at stage $i$; $\mathrm{d} h$ is the change in height induced by a vertical stress increment $\mathrm{d} \sigma_{v}^{\prime}$. In Figure $9, E_{\text {Oedo }}$ is plotted versus the vertical stress for both loading and unloading paths in a logarithmic plane. The results showed that there is an overall linear relationship between $\log E_{\text {Oedo }}$ and $\log \sigma^{\prime}{ }_{v}$, indicating a power function between $E_{\text {Oedo }}$ and $\sigma_{v}^{\prime}$.

\subsection{Isotropic consolidation tests}

The isotropic consolidation curves are shown in Figure 10. After the re-saturation under $p$ ' equal to the estimated in situ stress, a step loading was applied up to $p^{\prime}=20 \mathrm{MPa}$. Afterwards, unloading was applied in steps to $p^{\prime}=0.5 \mathrm{MPa}$. The volume change was considered as stabilized when the volumetric strain was lower than $10^{-6} / \mathrm{min}$ (AFNOR, 2005b). Note that data of the unloading path in test Ess83Iso1 are not available due to a technical problem that took place during the test.

Figure 10 presents the compression curves in $e$-logp' plot for Ess75, Ess83, Ess96 and Ess104. It can be observed that all samples show a normally consolidated behaviour, suggesting that the yield stress $p_{y}^{\prime}$ is equal to the in situ effective stress. Note that this behaviour is different from 
that of Boom clay at Mol since most studies have showed that the latter is over consolidated with an over consolidation ratio (OCR) comprised between 1.7 and 2.0 (Bouazza et al. 1996).

As for oedometer tests, the isotropic tests results in Figure 10 are used to determine the compressibility parameters $C_{c}\left(C_{c}=\mathrm{d} e / \mathrm{d} \log p^{\prime}\right.$ in the loading path $)$ and $C_{s}\left(C_{s}=\mathrm{d} e / \mathrm{d} \log p\right.$ ' in the unloading path). All these values of $C_{c}$ and $C_{s}$ are also reported in Table 4. Similar $C_{c}$ values are obtained for tests Ess75Iso1, Ess83Iso1, and Ess104Iso1; a significantly lower value is obtained for test Ess96Iso1. This is likely due to a technical problem that happened to the pressure/volume controller during the loading path. The $C_{s}$ values obtained from the three tests are close: 0.216 for test Ess75Iso1; 0.186 for test Ess96Iso1 and 0.177 for test Ess104Iso1.

Comparison between the values of $C_{c}$ and $C_{s}$ from the isotropic consolidation test and those from oedometer test shows that similar values $C_{c}$ were obtained; by contrast, the values of $C_{s}$ from isotropic tests are slightly lower than that from oedometer tests (Table 4). That is probably due to the effect of stress conditions.

\subsection{Triaxial shear tests}

Three triaxial shear tests were carried out on each core. In the first test, after consolidation under the in situ effective stress, the sample was sheared directly under a constant confining pressure equal to the in situ effective stress. In the two other tests, the samples were consolidated first under the corresponding in situ stress, then unloaded to 1.0 and $0.5 \mathrm{MPa}$ respectively. Shearing was performed afterwards as in the first test. Note that shear tests were conducted at a constant rate of $0.001 \mathrm{~mm} / \mathrm{min}$. This rate is defined according to the French standard, AFNOR (2005b), and corresponds to an axial strain rate of $1.31 \times 10^{-5} / \mathrm{min}$. This rate is considered as low enough to ensure the drained conditions of the test and no pore pressure build-up was checked.

Three cores were investigated: Ess75 at 219-m depth, Ess83 at 227-m depth and Ess96 at 240$\mathrm{m}$ depth. The results are shown in Figure 11 with a presentation of four plots: $p$ ' $q, q-\varepsilon_{a}, \varepsilon_{a}$ $\varepsilon_{v}, p^{\prime}-\varepsilon_{v}$. For the tests on Ess75, clear peaks in deviator stress were observed under both 0.5 and 1.0 MPa confining pressure and on the contrary, no deviator stress peak can be observed for the test under the in situ stress (2.2 MPa). This latter corresponds to a normally consolidated behaviour, which is in agreement with the results from isotropic compression tests (Figure 10). Changes in volumetric strain show that dilatancy occurred during the test Ess75Tr03 under a confining pressure of $0.5 \mathrm{MPa}$. By contrast, the two other tests showed a contraction solely. Similar observations can be made on the results from the tests on Ess83: clear deviator peaks were identified on the two over-consolidated samples under a confining pressure of 0.5 and $1 \mathrm{MPa}$ respectively. No peak was obtained for the normally consolidated sample under a confining pressure of 2.3 MPa. Dilatancy was observed in test Ess83Tr03 under a confining pressure of $0.5 \mathrm{MPa}$ whilst sole contraction volume change behaviour was observed in the two other tests under higher confining pressures. For tests on Ess96, it seems that only test Ess96Tr03 under a confining pressure of $0.5 \mathrm{MPa}$ presented a deviator peak; no obvious peaks were observed in the two other tests. For the volume change behaviour, only test Ess96Tr03 showed dilatancy.

The shear strength parameters (effective cohesion $c^{\prime}$ and internal friction angle $\varphi^{\prime}$ ) and initial tangent modulus $\left(E_{0}=q / \varepsilon_{a}\right)$ are determined from the results presented in Figure 11. The values are shown in Table 5. It can be observed that the modulus $E_{0}$ is confining pressure dependent. 
Indeed, the $E_{0}$ values of Ess75, Ess83 and Ess96 are about $100-200 \mathrm{MPa}$ at $2.2 \mathrm{MPa}$ confining pressure, 50-70 $\mathrm{MPa}$ at 1.0 $\mathrm{MPa}$ confining pressure and 20-30 $\mathrm{MPa}$ at $0.5 \mathrm{MPa}$ confining pressure. For the shear strength parameters, an effective cohesion $c^{\prime}$ of $0.1-0.2 \mathrm{MPa}$ and a fiction angle $\varphi^{\prime}$ of $12-14^{\circ}$ were obtained.

\section{Discussion}

The volume change properties and deviator behaviour of Boom clay at Essen have been investigated. The Boom clay at Mol has been also studied by several tests. The results obtained enable a preliminary comparison between Boom clay from the two different sites.

\subsection{Volume change behaviour}

As the initial void ratios of Boom clay at Essen and at Mol are different, it is difficult to make a direct comparison of their compression behaviour. To overcome this problem, the concept of the void index $\left(I_{v}\right)$ developed by Burland (1990) is used, allowing the compression curves of different soils to be normalised. The void index is defined as follows: $I_{v}=\left(e-e_{100} *\right) /\left(e_{100}{ }^{*}-\right.$ $e_{1000} *$ ), where $e$ is the void ratio of soil sample; $e_{100} *$ and $e_{1000} *$ are void ratios of reconstituted samples at 100 and $1000 \mathrm{kPa}$ stress, respectively. If no test data are available, $e_{100} *$ and $e_{1000} *$ may be estimated using the following empirical equations: $e_{100} *=0.109+0.679 e_{L}-0.089 e_{L}{ }^{2}$ $+0.016 e_{L}^{3}$ and $\left(e_{100} *-e_{1000} *\right)=0.256 e_{L}-0.04$, where $e_{L}$ is the void ratio at the liquid limit. Burland (1990) stated that the previous empirical equations should only be used for $e_{L}$ within the range of $0.6-4.5$ (i.e., $w_{L}=25-160 \%$ ). Burland (1990) also related the in situ void index to the effective overburden stress based on the data from compression tests on natural sedimentary clays reported by Skempton (1970). This relationship was called the sedimentation compression line (SCL). The in situ void index $\left(I_{v 0}\right)$ was defined as follows: $I_{v 0}=\left(e_{0}-\right.$ $\left.e_{100} *\right) /\left(e_{100} *-e_{1000} *\right)$ where $e_{0}$ is the in situ void ratio. Burland (1990) reported that the compression curves of reconstituted clays can be normalized well using the void index: the normalized compression curve can be expressed reasonably by an unique void index - stress line, which is designated as the intrinsic compression line (ICL): $I_{v}=2.45-1.285 \log \sigma_{v}{ }_{v}+$ $0.015 \log \sigma_{v}^{3}$, where $\sigma_{v}$ is expressed in $\mathrm{kPa}$.

Based on the void index concept, the values of $e_{100} *$ and $\left(e_{100} *-e_{1000} *\right)$ can be calculated for Boom clay. The results are shown in Table 6. Note that in the calculation for Boom clay at Mol an average value of $68 \%$ was considered for the liquid limit $w_{L}$. It can be observed that the values of $e_{100} *$ and $\left(e_{100^{*}}-e_{1000} *\right)$ for Ess83, Ess96, Ess104 and Mol are almost the same, equal to 1.11-1.12 and 0.42-0.43, respectively. Nevertheless, the values for Ess75 and Ess112 are significantly different. Interestingly, the mineralogy and particle size distribution curves are also similar for Ess83, Ess96, Ess104 and Mol, different from that of Ess75 and Ess112.

The void index $I_{v}$ was then calculated using the parameters shown in Table 6 and the void ratio corresponding to each step. That allowed plotting the compression curves in the plot $I_{v}-\log \sigma_{v}$ as shown in Figure 12. Note that only loading paths are considered in this analysis. The path B$>\mathrm{C}$ corresponds to the loading from $0.125 \mathrm{MPa}$ to $16 \mathrm{MPa}$, and the path $\mathrm{D}->\mathrm{E}$ corresponds to the loading from $0.125 \mathrm{MPa}$ to $32 \mathrm{MPa}$, both in high pressure oedometer. The path II->III corresponds to loading from $0.05 \mathrm{MPa}$ to $3.2 \mathrm{MPa}$ in low pressure oedometer. It should be mentioned that before the B->C and II-> III stages, the maximum effective stress was $2.4 \mathrm{MPa}$, while before the D->E stage the maximum effective stress was $16.0 \mathrm{MPa}$. It can be observed that with a pre-consolidation stress $\sigma_{c}^{\prime}=2.4 \mathrm{MPa}$ (B->C and II-III), the curves are convex and situated below SCL; they cross ICL at about 1.0 MPa and overlap at 16-32 MPa. With a preconsolidation stress $\sigma^{\prime}{ }_{c}=16 \mathrm{MPa}(\mathrm{D}->\mathrm{E})$, the curves are also convex but they cross ICL at 4 - 
$8 \mathrm{MPa}$. This phenomenon was also observed on rocks and clays with a low void ratio (Burland, 1990; Low et al., 2008). Actually, the ICL is established based on the results on reconstituted clays that have high void ratios, whose shape is concave in the $I_{v}-\log \sigma_{v}{ }_{v}$ plot. By contrast, for low-void ratio stiff clays as Boom clay, the pore-breaking by loading is more progressive and thus convex curves are obtained.

Comparison of the $I_{v}-\log \sigma_{v}^{\prime}$ curves for B->C and II->III stages shows that when $\sigma_{v}^{\prime}$ is higher than the pre-consolidation stress $\sigma_{c}^{\prime}=2.4 \mathrm{MPa}$, the two curves overlap. When $\sigma_{v}^{\prime}$ is lower than $\sigma_{c}^{\prime}=2.4 \mathrm{MPa}$, the two curves are separated and the difference between the two curves are due to the different swelling strains under different initial load $(0.125 \mathrm{MPa}$ in Oedo1 and $0.05 \mathrm{MPa}$ in Oedo2). For D->E stage, when $\sigma_{v}^{\prime}$ is higher than the pre-consolidation stress $\sigma_{c}^{\prime}=16 \mathrm{MPa}$, the curves join the B->C curves. This suggests that the initial swelling does not affect the compression behaviour after the pre-consolidation stress.

To further analyse the compression behaviour of Boom clay at both Mol and Essen, all the results in Figure 12 are gathered in Figure 13. It appears that when the vertical effective stress is lower than the pre-consolidation stress $\sigma_{c}^{\prime}(2.4 \mathrm{MPa}$ for B->C and II->III and $16 \mathrm{MPa}$ for D$>\mathrm{E}$ ), the curves are separated; on the contrary when the vertical effective stress is higher than $\sigma_{c}^{\prime}$, the curves almost overlap whatever the cores and the loading history. That suggests existence of a constant compression line after the pre-consolidation stress for Boom clay, as the dashed line in Figure 13 situated between ICL and SCL.

\subsection{Shear strength}

The effective cohesion $c^{\prime}$ and internal friction angle $\varphi^{\prime}$ of reconstituted Boom clay at Mol was $0.01 \mathrm{MPa}$ and $18.5^{\circ}$ respectively (Bouazza et al., 1996); the values for intact Boom clay are $0.18 \mathrm{MPa}$ and $18^{\circ}$ respectively (Coll, 2005). Table 5 shows that the $c$ ' values of Boom clay at Essen are similar to that at Mol; but relatively smaller values of $\varphi^{\prime}$ have been found for Boom clay at Essen $\left(12.4-13.5^{\circ}\right.$ against $\left.18^{\circ}\right)$.

To further analyse this difference, the results on Boom clay at Mol by various authors (Horseman et al., 1987; Sultan, 1997; Van Impe, 1993; Baldi, et al., 1991; Coll, 2005) and the results on Boom clay at Essen are gathered in Figure 14. The failure envelope of the reconstituted Boom clay at Mol (Bouazza et. al., 1996), that of intact Boom clay at Mol (Coll, 2005) and that of Boom clay at Essen are also plotted. It can be observed that the failure envelope of intact Boom clay at Mol is not linear, especially in the lower stress part ( $p$ ' lower than 2.0 MPa). The part of higher stress is linear with a slope $M=0.46$ that corresponds to a friction angle $\varphi^{\prime}$ of $12.5^{\circ}$. Interestingly, the $p$ ' value of $2.0 \mathrm{MPa}$ is close to the in-situ effective stress $\sigma_{c}^{\prime}$. A linear failure envelope is observed for reconstituted Boom clay at Mol with a slope $M=0.71$ that corresponds to $\varphi^{\prime}=18.5^{\circ}$ (Bouazza et al., 1996). Burland et al. (1996) analyzed the failure envelopes of four stiff clays (Todi Clay, Pietrafitta Clay, Vallericca clay and and Corinth marl), and also showed the difference between intact and reconstituted clays. From this analysis, it appears that the value of $\varphi^{\prime}$ equal $18^{\circ}$ proposed by Coll (2005) is too large and it was resulted from the consideration of one sole linear failure envelope.

For the failure envelope of Boom clay at Essen (dashed line in Figure 14), it is also non linear. Moreover, the part of high stress (p'> $2 \mathrm{MPa}$ ) is almost parallel to that of Boom clay at Mol, defining a similar internal friction angle (about $13^{\circ}$ ). As there are a few points compared to Boom clay at Mol, the stress value that separates the non linear part from the linear part is not 
clear for Boom clay at Essen. More tests are needed to complete this study. In spite of this, a separating stress close to the in situ effective stress (about $2 \mathrm{MPa}$ ) can be expected based on the results on Boom clay at Mol.

The fact that the failure envelope of intact Mol Boom clay is above that of reconstituted Mol Boom clay and Essen Boom clay suggest a significant effect of carbonate content. Indeed, Mol Boom clay has much higher carbonate content than Essen Boom clay, and shows higher shear strength due to the cementation effect by carbonates. This cementation can be expected to be destroyed when reconstituting the sample.

\subsection{Yield stress and pre-consolidation stress}

Horseman et al. (1987) performed an oedometer test on intact Boom clay at Mol with loading from 1.0 to $6.0 \mathrm{MPa}$, unloading to $1.0 \mathrm{MPa}$, reloading to $8.0 \mathrm{MPa}$, unloading to $1.0 \mathrm{MPa}$, reloading to $32 \mathrm{MPa}$ and unloading to $0.5 \mathrm{MPa}$. These results are re-analyzed using $I_{v}-\log \sigma_{v}$, plot, together with the results from test MolOedo1 (Figure 15). The data of Horseman et al. (1987) indicate a yield stress $\sigma_{y}^{\prime}$ of $6 \mathrm{MPa}$. This value was considered by Horseman et al. (1987) as the pre-consolidation stress $\sigma_{c}^{\prime}$ in the determination of the over-consolidation ratio $(\mathrm{OCR}=2.4)$. On the contrary, the high pressure oedometer test Mol01 indicates a lower yield stress $\sigma_{y}^{\prime}$ of $1.9 \mathrm{MPa}(\mathrm{B}->\mathrm{C})$. On the other hand, the analysis above shows that the compression curves of stiff clays cross the ICL and lie between the ICL and the SCL beyond the preconsolidation stress, which indicates that the Boom clay at Mol is only slightly overconsolidated. This observation suggests that, for stiff clays such as Boom clay, the OCR value cannot be estimated only based on the yield stress identified from oedometer tests. In other words, $\sigma_{y}^{\prime}$ and $\sigma_{c}^{\prime}$ are two different notions. It has been observed that the pre-consolidation stress $\sigma_{c}^{\prime}$ significantly affects the volume change behaviour and shear strength; to reach the 'virgin' state, it is necessary to apply a pressure beyond $\sigma_{c}$, higher than $\sigma_{\mathrm{y}}$, for Boom clay.

\section{Conclusion}

In order to verify the transferability of knowledge on Boom clay between different sites, Boom clay taken from two sites (Mol and Essen) were studied by performing low-pressure and highpressure oedometer tests, isotropic compression tests and triaxial shear tests. The results obtained allow the following conclusions to be drawn:

(1) Examination of the geotechnical properties and the mineralogy indicate that the Boom clay from the Essen site at depths of 227, 240 and 248-m is similar to Boom clay from the Mol site, but there are significant differences with the Boom clay from Essen at 219 and 256-m depths. This is confirmed by the values of $e_{100} *$ and $\left(e_{100} *-e_{1000} *\right)$. Indeed, for Ess83, Ess96, Ess104 and Mol the same values were obtained, equal to 1.11-1.12 and 0.42-0.43, respectively; but different values were obtained on Ess75 and Ess112.

(2) Below the pre-consolidation stress $\sigma_{c}^{\prime}$, the compression curve in void index $I_{v}$ depends on the loading path and history, whilst beyond the pre-consolidation stress, the curve becomes a straight line situated between the intrinsic compression line (ICL) and the sedimentation compression line (SCL).

(3) The yield stress $\sigma_{y}^{\prime}$ and the pre-consolidation stress $\sigma_{c}^{\prime}$ are two different notions. $\sigma_{y}^{\prime}$ is stress-path dependent and it is lower than $\sigma_{c}^{\prime}$ for Boom clay. Thus estimating OCR using $\sigma_{y}^{\prime}$ would lead to lower values than the real ones. 
(4) The volume change behaviour depends significantly on the pre-consolidation stress $\sigma_{c}$. Beyond $\sigma_{c}^{\prime}$ the $I_{v}$ compression line becomes unique; in terms of failure envelopes, they become parallel beyond $\sigma_{c}^{\prime}$, suggesting the same internal friction angle (about $13^{\circ}$ for both Boom clay at Essen and Mol).

(5) The failure envelope of intact Mol Boom clay is above that of reconstituted Mol Boom clay and Essen Boom clay, suggesting a significant effect of carbonate content en Boom clay shear strength.

\section{Acknowledgements}

ONDRAF/NIRAS (The Belgian Agency for Radioactive Waste and Enriched Fissile Materials) is gratefully acknowledged for its financial support. The first author is grateful to the National Science Foundation of China for its support.(No 50908049).

\section{References:}

AFNOR, 1995. Sols : reconnaissance et essais: essai de gonflement à l'oedomètre, détermination des déformations par chargement de plusieurs éprouvettes. XP P 94-091.

AFNOR, 2005a. Geotechnical investigating and testing, Laboratory testing of soils, Part 5: Incremental loading Oedometer test. XP CEN ISO/TS 17892-5.

AFNOR, 2005b. Laboratory testing of soils: Part 9: Consolidated triaxial compression tests on water saturated soils. XP CEN ISO/TS 17892-9.

Baldi, G., Hueckel, T., Peano, A. and Pellegrini, R. 1991. Developments in modelling of thermo-hydro-geomechanical behaviour of Boom Clay and clay-based buffer materials. ISMES, Final report, EUR 13365/1, 134 p.

Bernier, F., Li, X. L., and Bastiaens, W. 2007. Twenty-five years' geotechnical observation and testing in the Tertiary Boom clay formation. Géotechnique, 57(2): 229 - 237.

Bouazza, A., Van Impe, W. F., and Haegeman W. 1996. Some mechanical properties of reconstituted Boom. Geotechnical and Geological Engineering, 14(4): 341-352.

Burland, J. B., 1990. On the compressibility and shear strength of natural clays. Géotechnique, 40(3): 329-378.

Burland, J. B., Rampello, S., Georgiannou, V. N. and Calabresi, G. 1996. A laboratory study of the strength of four stiff clays. Géotechnique, 46(3): 491-514.

Coll, C., 2005. Endommagement des roches argileuses et perméabilité induite au voisinage d'ouvrage souterrains. Ph.D. thesis, Université Joseph Fourier-Grenoble 1, Grenoble.

Cui, Y.J., Le, T.T., Tang, A.M., Delage, P., and Li, X.L. 2009. Investigating the time dependent behavior of Boom clay under thermomechanical loading. Géotechnique, 59(4): 319-329.

De Craen, M., Wemaere, I., Labat, S., and Van Geet, M. 2006. Geochemical analyses of Boom Clay pore water and underlying aquifers in the Essen-1 borehole. External report, SCK.CEN-ER-19, 06/MDC/P-47, Belgium

Delage, P., Le, T.T., Tang, A.M., Cui, Y.J., and Li, X.L. 2007. Suction effects in deep Boom clay samples. Géotechnique, 57(2): 239-244.

Francois, B., Laloui, L., and Laurent, C. 2009. Thermo-hydro-mechanical simulation of ATLAS in situ large scale test in Boom Clay. Computers and Geotechnics, 36(4): 626640.

Horseman, S.T., Winter, M.G. and Entwistle, D.C. 1987, Geotechnical characterization of Boom clay in relation to the disposal of radioactive waste. Commission of the European Communities, $87 \mathrm{p}$. 
Labat, S., Marivoet, J., Wemaere, I., and Maes, T. 2008. Essen-1 borehole of the hydro/05neb campaign: technical aspects and hydrogeological investigations. External report, SCK.CEN-ER-68, 08/SLa/P-20.

Low, H. E., Phoon, K. K., Tan, T. S. and Leroueil, S. 2008. Effect of soil microstructure on the compressibility of natural Singapore marine clay. Canadian Geotechnical Journal, 45(2): 161-176.

Skempton, A. W., 1970. The consolidation of clays by gravitational compaction. Quarterly Journal of the Geological Society, 125: 373-411.

Sultan N., 1997. Etude du comportement thermo-mécanique de l'argile de Boom: expériences et modélisation. Thèse de doctorat, Ecole Nationale des Ponts et Chaussées, 310 p.

Van Impe W.F., 1993. Boom clay for storage of nuclear waste (discussion session 2b). Geotechnical Engineering of Hard Soils-Soft Rocks, Athen, Al. A. E. (eds), Balkema, Rotterdam, 3: 1885-1895.

Wemaere, I., Marivoet, J., and Labat, S. 2008. Hydraulic conductivity variability of the Boom Clay in north-east Belgium based on four core drilled boreholes. Physics and Chemistry of the Earth, 33(S1): 24-36. 


\section{List of Tables}

Table 1. Geotechnical properties of the soil cores studied

Table 2. Mineralogical composition of soil cores

Table 3. Mineralogical composition of clay fraction $(<2 \mu \mathrm{m})$

Table 4. Compressibility parameters

Table 5. Results from triaxial shear tests

Table 6. Parameters used to calculate the void index $I_{v}$

\section{List of Figures}

Figure 1. Location of the drilled borehole - Essen (De Craen et al., 2006)

Figure 2. Stratigraphical log from the Essen-1 borehole (Labat et al., 2008)

Figure 3. Hydrogeological cross-section (Wemaere et al., 2008)

Figure 4. Particle size distribution curves

Figure 5. Oedometer test: vertical effective stress and displacement versus elapsed time (Ess750edo1)

Figure 6. Compression curves from oedometer tests (Ess750edo1 and Ess750edo2)

Figure 7. Determination of the compressibility parameters (Ess75Oedo1)

Figure 8. Compression curves from oedometer tests

Figure 9. Oedometer modulus versus vertical effective stress

Figure 10. Compression curves from isotropic consolidation tests

Figure 11. Results from triaxial shear tests on Ess75, Ess83 and Ess96

Figure 12. $I_{v}-\sigma^{\prime}{ }_{v}$ curves for Boom clay at Essen and Mol

Figure 13. $I_{v}-\sigma^{\prime}{ }_{v}$ curves for all cores studied

Figure 14. Failure envelopes in $p^{\prime}-q$ plane for intact and reconstituted Boom clay at Mol, and intact Boom clay at Essen

Figure 15. $I_{v}-\sigma^{\prime}{ }_{v}$ curves for Boom clay at Mol 
Table 1. Geotechnical properties of the soil cores studied

\begin{tabular}{|c|c|c|c|c|c|c|c|c|c|c|c|}
\hline Core & $\begin{array}{l}\text { Depth } \\
\text { (m) }\end{array}$ & Member & $\mathrm{G}_{\mathrm{s}}$ & $\begin{array}{l}W_{L} \\
(\%)\end{array}$ & $\begin{array}{l}W_{p} \\
(\%)\end{array}$ & $\begin{array}{c}I_{p} \\
(\%)\end{array}$ & w & $\mathrm{e}_{0}$ & $\mathrm{~S}_{\mathrm{r}}$ & $\mathrm{MB}$ & Carbonate content (\%) \\
\hline Ess75 & $\begin{array}{l}218.91- \\
219.91\end{array}$ & Putte & 2.65 & 78 & 33 & 45 & 29.7 & 0.785 & 1.00 & 6.47 & 0.91 \\
\hline Ess83 & $\begin{array}{l}226.65- \\
227.65\end{array}$ & Putte & 2.64 & 70 & 33 & 37 & 27.2 & 0.730 & 0.98 & 6.67 & 0.76 \\
\hline Ess96 & $\begin{array}{l}239.62- \\
240.62\end{array}$ & Terhagen & 2.68 & 69 & 33 & 36 & 26.5 & 0.715 & 0.99 & 6.20 & 0.24 \\
\hline Ess104 & $\begin{array}{c}247.90- \\
248.91\end{array}$ & Terhagen & 2.68 & 68 & 29 & 39 & 27.7 & 0.700 & 1.00 & 6.67 & 4.36 \\
\hline Ess112 & $\begin{array}{l}255.92- \\
256.93\end{array}$ & Terhagen & 2.67 & 62 & 25 & 37 & 27.3 & 0.755 & 0.97 & 6.83 & 2.64 \\
\hline $\mathrm{Mol}^{*}$ & 223 & Putte & 2.67 & $59-83$ & $22-28$ & & $9.5-40$ & $0.49-0.67$ & 1.00 & 2.67 & $5.9-8.3$ \\
\hline
\end{tabular}

* From Francois et al. (2009).

Table 2. Mineralogical composition of soil cores

\begin{tabular}{c|c|c|c|c|c|c|c|c|c}
\hline \hline \multirow{2}{*}{ Core } & \multicolumn{7}{c}{ Mineral content (\% ) } \\
\cline { 2 - 14 } & Quartz & Feldspath K & $\begin{array}{c}\text { Illite / } \\
\text { Mica }\end{array}$ & Kaolinite & Pyrite & Calcite & Gypsum & \multirow{2}{*}{ Jarosite } & \multirow{2}{*}{ Sulfur } \\
\hline \hline Ess75 & 40 & + & 15 & 40 & + & & ++ & 5 & + \\
\hline Ess83 & 60 & ++ & 10 & 30 & ++ & & + & & \\
\hline Ess96 & 70 & ++ & 10 & 20 & + & & & & \\
\hline Ess104 & 65 & + & 10 & 20 & ++ & 5 & & & \\
\hline Ess112 & 70 & 5 & 10 & 15 & ++ & ++ & & & \\
\hline Mol & 60 & + & 10 & 30 & + & + & + & & \\
\hline \hline
\end{tabular}


Table 3. Mineralogical composition of clay fraction $(<2 \mu \mathrm{m})$

\begin{tabular}{c|c|c|c|c|c}
\hline \hline \multirow{2}{*}{ Core } & \multicolumn{5}{|c}{ Mineral content (\%) } \\
\cline { 2 - 6 } & Chlorite & Kaolinite & Illite & Smectite & Ill/Smecta \\
\hline \hline Ess75 & 5 & 35 & 20 & 10 & 30 \\
\hline Ess83 & 5 & 35 & 20 & 20 & 20 \\
\hline Ess96 & 5 & 35 & 20 & 10 & 30 \\
\hline Ess104 & 5 & 35 & 15 & 30 & 15 \\
\hline Ess112 & 5 & 35 & 10 & 50 & 10 \\
\hline Mol & 5 & 35 & 20 & 10 & 30 \\
\hline \hline
\end{tabular}


Table 4. Compressibility parameters

\begin{tabular}{|c|c|c|c|c|c|c|c|c|c|c|c|c|c|}
\hline \multirow[b]{2}{*}{ Core } & \multicolumn{6}{|c|}{\begin{tabular}{|l|l} 
Oedo 1 \\
\end{tabular}} & \multicolumn{4}{|c|}{ Oedo 2} & \multicolumn{3}{|c|}{ Iso } \\
\hline & $C_{c}$ & $C_{S A->B}$ & $\begin{array}{l}\sigma_{y B->C}^{\prime} \\
(\mathrm{MPa})\end{array}$ & $C_{S C->D}$ & $\begin{array}{l}\sigma_{y D->E}^{\prime} \\
(\mathrm{MPa})\end{array}$ & $C_{S E->F}$ & $C_{c}$ & $C_{S I->I I}$ & $\begin{array}{l}\sigma_{y I I->I I I} \\
(\mathrm{MPa})\end{array}$ & $C_{\text {SIII->IV }}$ & $C_{c}$ & $\begin{array}{c}\sigma_{y}^{\prime} \\
(\mathrm{MPa})\end{array}$ & $C_{s}$ \\
\hline Ess75 & 0.378 & 0.105 & 1.4 & 0.165 & 1.4 & 0.158 & 0.221 & 0.134 & 0.33 & 0.140 & 0.383 & 2.2 & 0.216 \\
\hline Ess83 & 0.345 & 0.110 & 1.3 & \begin{tabular}{|l}
0.136 \\
\end{tabular} & 1.3 & 0.139 & 0.193 & 0.134 & 0.23 & 0.134 & 0.313 & 2.27 & \\
\hline Ess96 & 0.375 & 0.078 & 2 & \begin{tabular}{|l|l}
0.128 \\
\end{tabular} & 2 & 0.136 & 0.228 & & 0.35 & 0.142 & 0.280 & & 0.186 \\
\hline Ess104 & 0.327 & 0.066 & 1.8 & \begin{tabular}{|l|l|}
0.115 \\
\end{tabular} & 1.8 & 0.120 & 0.191 & 0.117 & 0.28 & 0.098 & 0.346 & 2.48 & 0.177 \\
\hline Ess112 & 0.302 & 0.041 & 2.2 & 0.076 & 2.2 & 0.082 & 0.123 & 0.100 & 0.25 & 0.095 & & & \\
\hline Mol & 0.405 & 0.099 & 1.9 & \begin{tabular}{|l|l|}
0.144 \\
\end{tabular} & 2.2 & 0.157 & 0.164 & 0.145 & 0.21 & 0.128 & & & \\
\hline
\end{tabular}


Table 5. Results from triaxial shear tests

\begin{tabular}{lccccc}
\hline \hline Core & Test & $\begin{array}{c}\text { Effective pressure } \\
(\mathrm{MPa})\end{array}$ & $\begin{array}{c}E_{0} \\
(\mathrm{MPa})\end{array}$ & $\begin{array}{c}c^{\prime} \\
(\mathrm{MPa})\end{array}$ & $\begin{array}{c}\varphi^{\prime} \\
\left({ }^{\circ}\right)\end{array}$ \\
\hline \hline \multirow{3}{*}{ Ess75 } & TR01 & 2.20 & 103.8 & & \\
& TR02 & 1.0 & 50.0 & 0.11 & 12.4 \\
& TR03 & 0.5 & 30.8 & & \\
\hline \multirow{4}{*}{ Ess83 } & TR01 & 2.28 & 200.0 & & \\
& TR02 & 1.0 & 63.9 & 0.18 & 13 \\
& TR03 & 0.5 & 35.6 & & \\
\hline \multirow{4}{*}{ Ess96 } & TR01 & 2.62 & 106.7 & & \\
& TR02 & 1.0 & 71.0 & 0.11 & 13.5 \\
& TR03 & 0.5 & 22.4 & & \\
\hline \hline
\end{tabular}


Table 6. Parameters used to calculate the void index $I_{v}$

\begin{tabular}{ccccccccc}
\hline \hline Core & $G_{s}$ & $\begin{array}{c}w_{L} \\
\%\end{array}$ & $\begin{array}{c}w_{p} \\
\%\end{array}$ & $\begin{array}{c}I_{p} \\
\%\end{array}$ & $e_{0}$ & $e_{L}$ & $e_{100} *$ & $e_{100} *_{-} e_{1000} *$ \\
\hline \hline Ess75 & 2.65 & 78 & 33 & 45 & 0.785 & 2.07 & 1.22 & 0.49 \\
Ess83 & 2.64 & 70 & 33 & 37 & 0.73 & 1.85 & 1.12 & 0.43 \\
Ess96 & 2.68 & 69 & 33 & 36 & 0.715 & 1.85 & 1.12 & 0.43 \\
Ess104 & 2.68 & 68 & 29 & 39 & 0.7 & 1.82 & 1.11 & 0.43 \\
Ess112 & 2.67 & 62 & 25 & 37 & 0.755 & 1.66 & 1.04 & 0.39 \\
Mol & 2.67 & 68 & & & 0.66 & 1.82 & 1.11 & 0.42 \\
\hline \hline
\end{tabular}




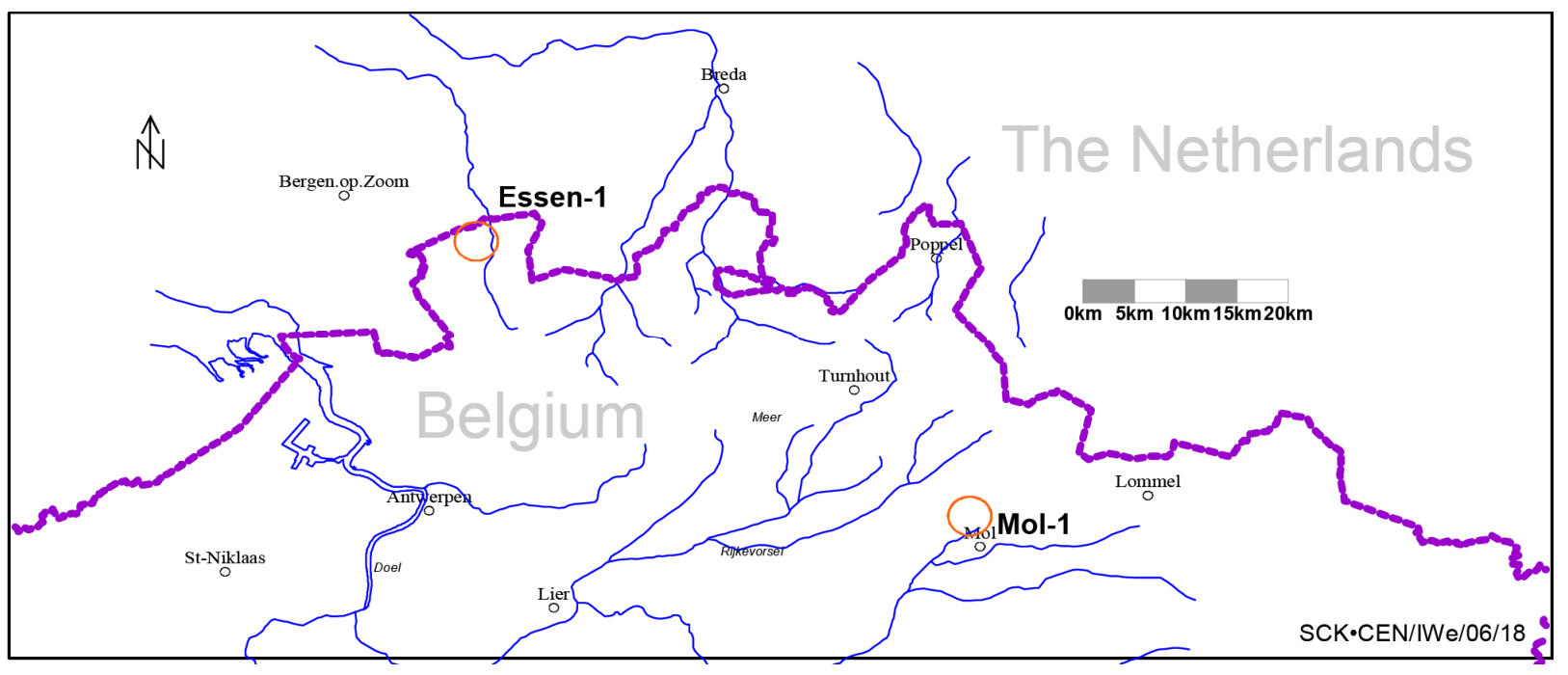

Figure 1. Location of the drilled borehole - Essen (De Craen et al., 2006) 


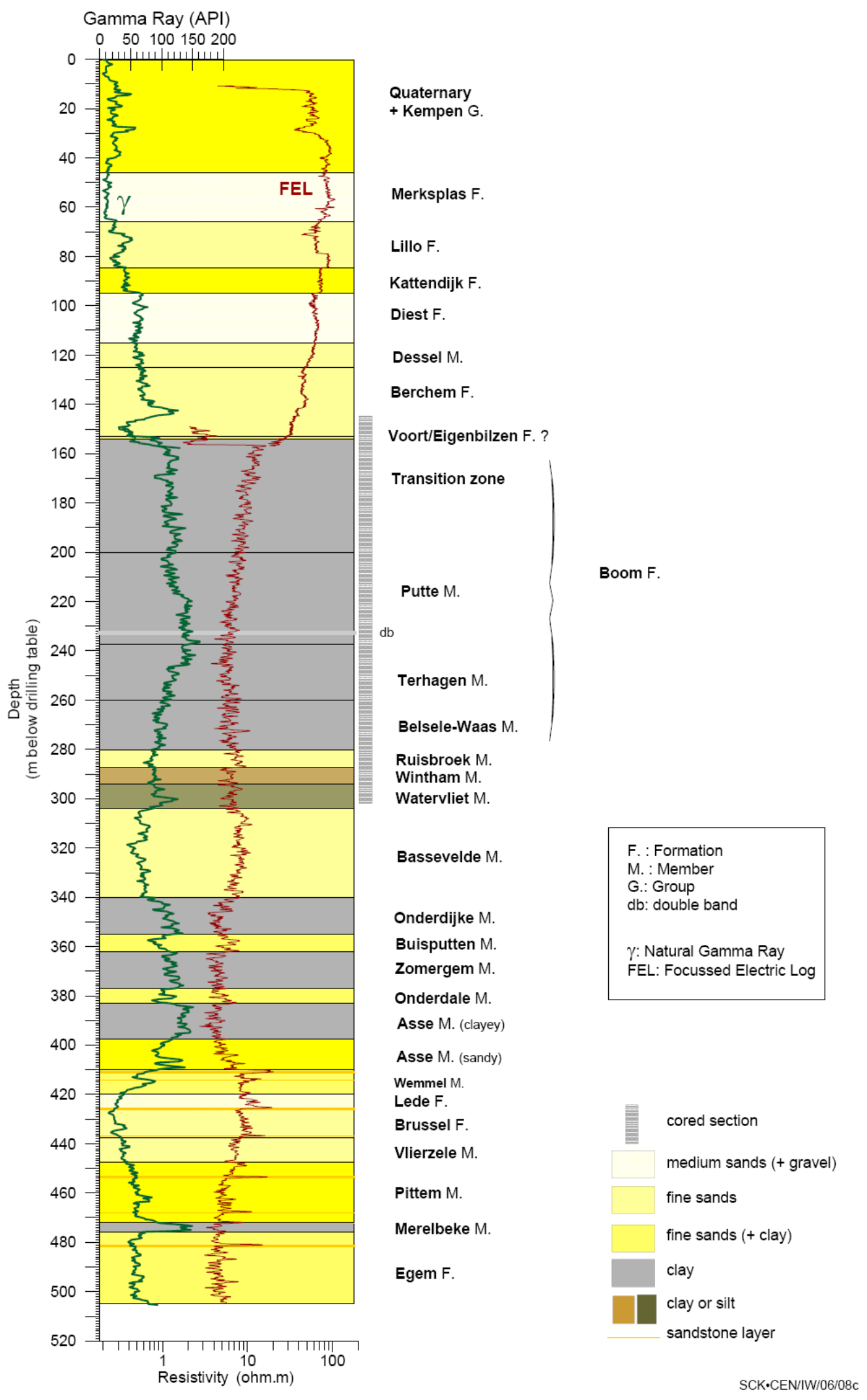

Figure 2. Stratigraphical log from the Essen-1 borehole (Labat et al., 2008) 


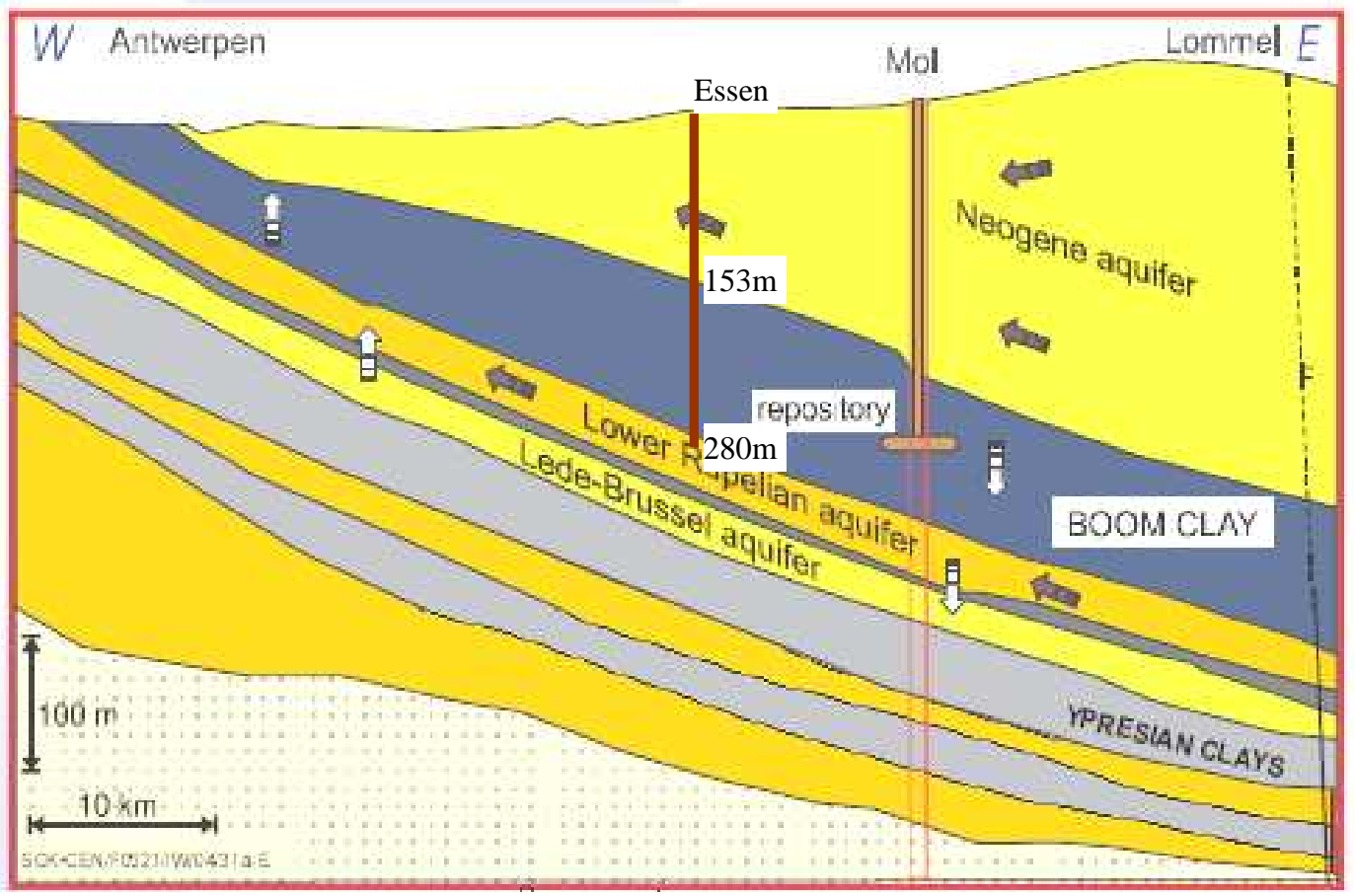

Figure 3. Hydrogeological cross-section (Wemaere et al., 2008) 


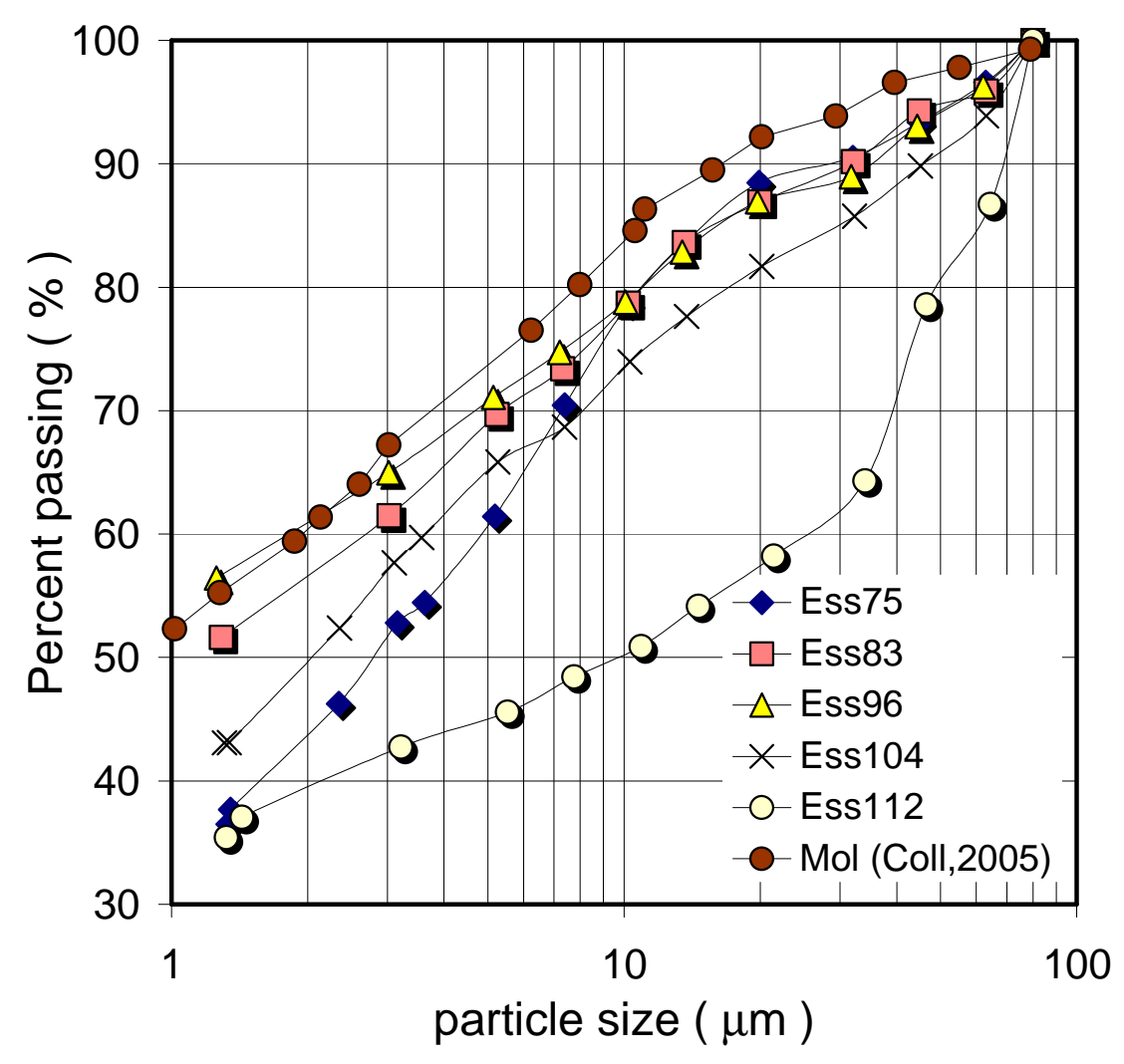

Figure 4. Particle size distribution curves 

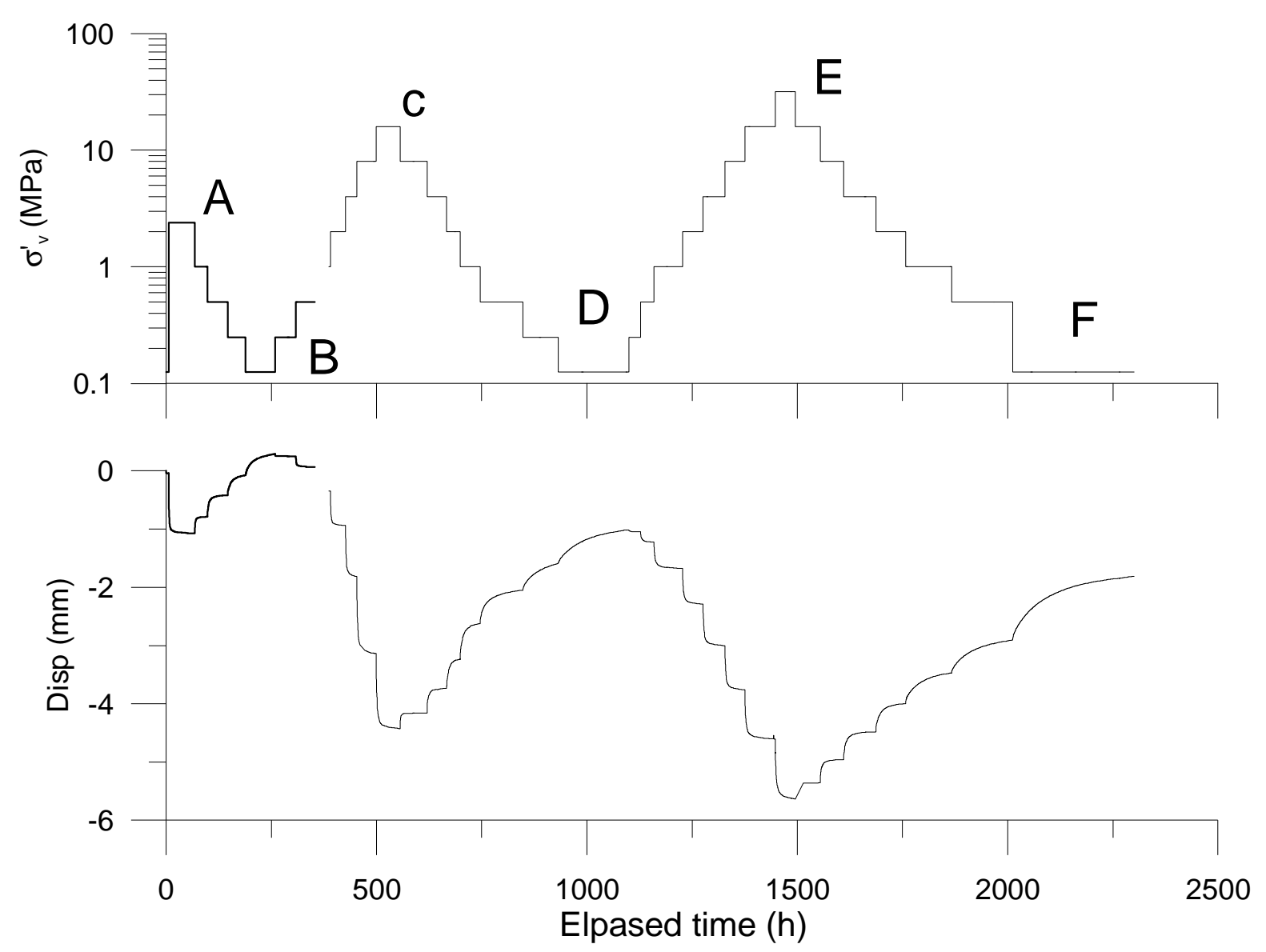

Figure 5. Oedometer test: vertical effective stress and displacement versus elapsed time (Ess750edo1) 


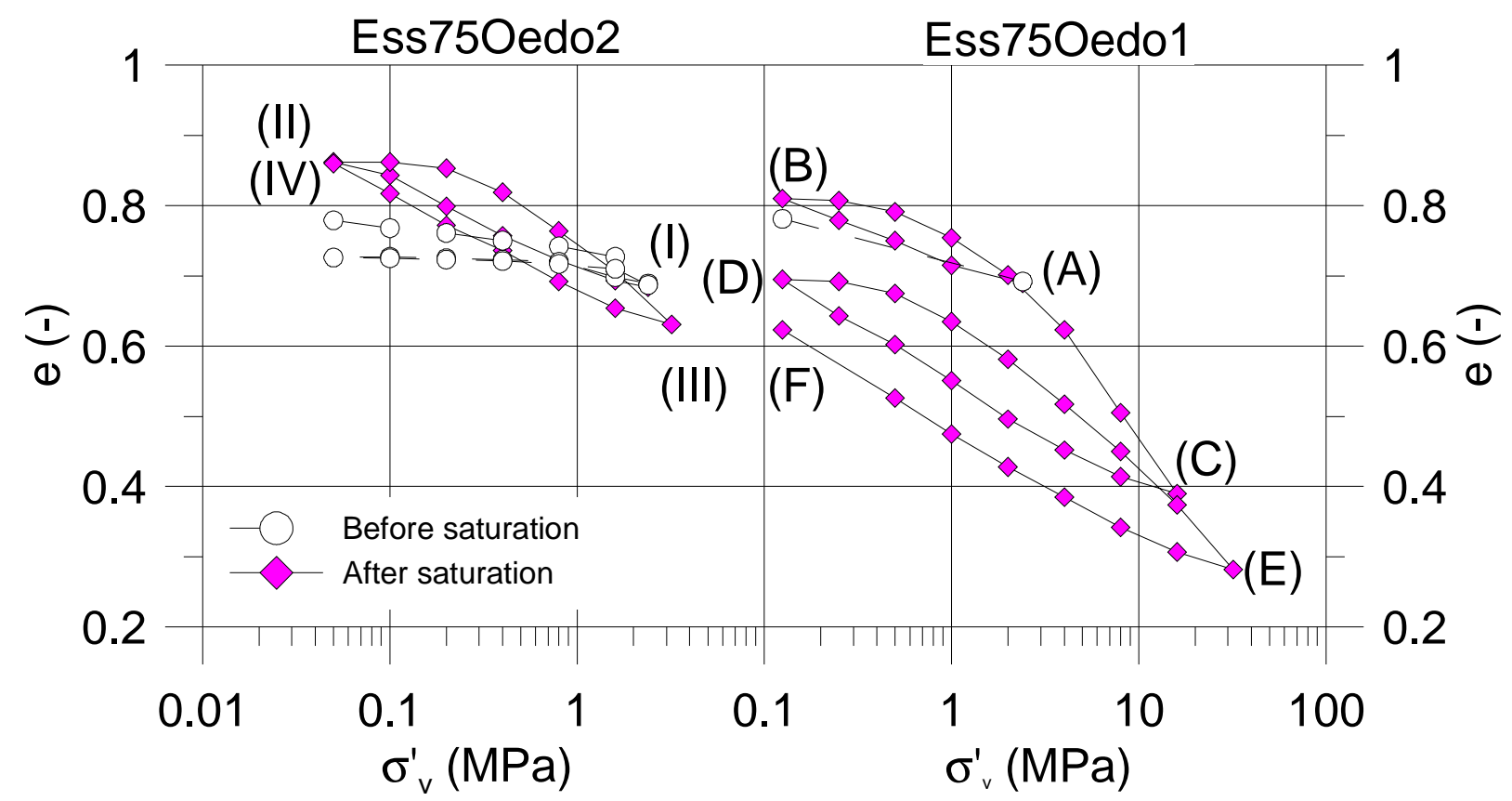

Figure 6. Compression curves from oedometer tests (Ess750edo1 and Ess750edo2)

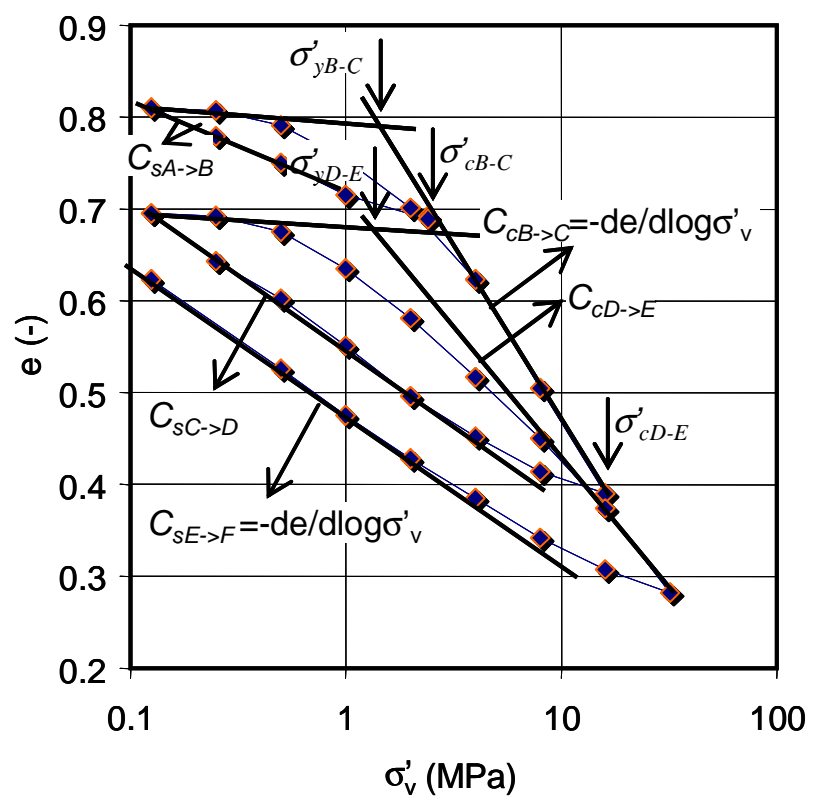

Figure 7. Determination of the compressibility parameters (Ess750edo1) 

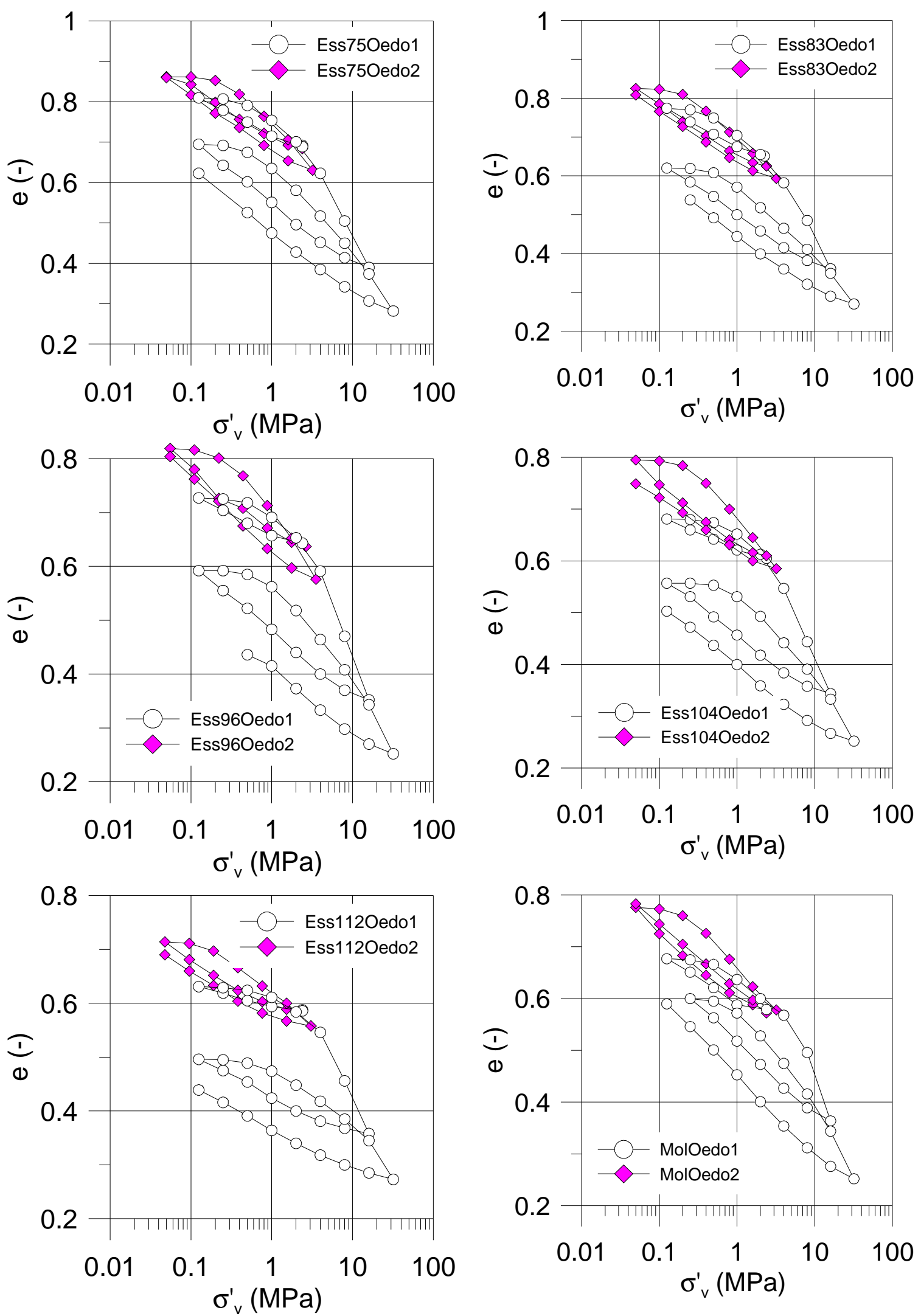

Figure 8. Compression curves from oedometer tests 

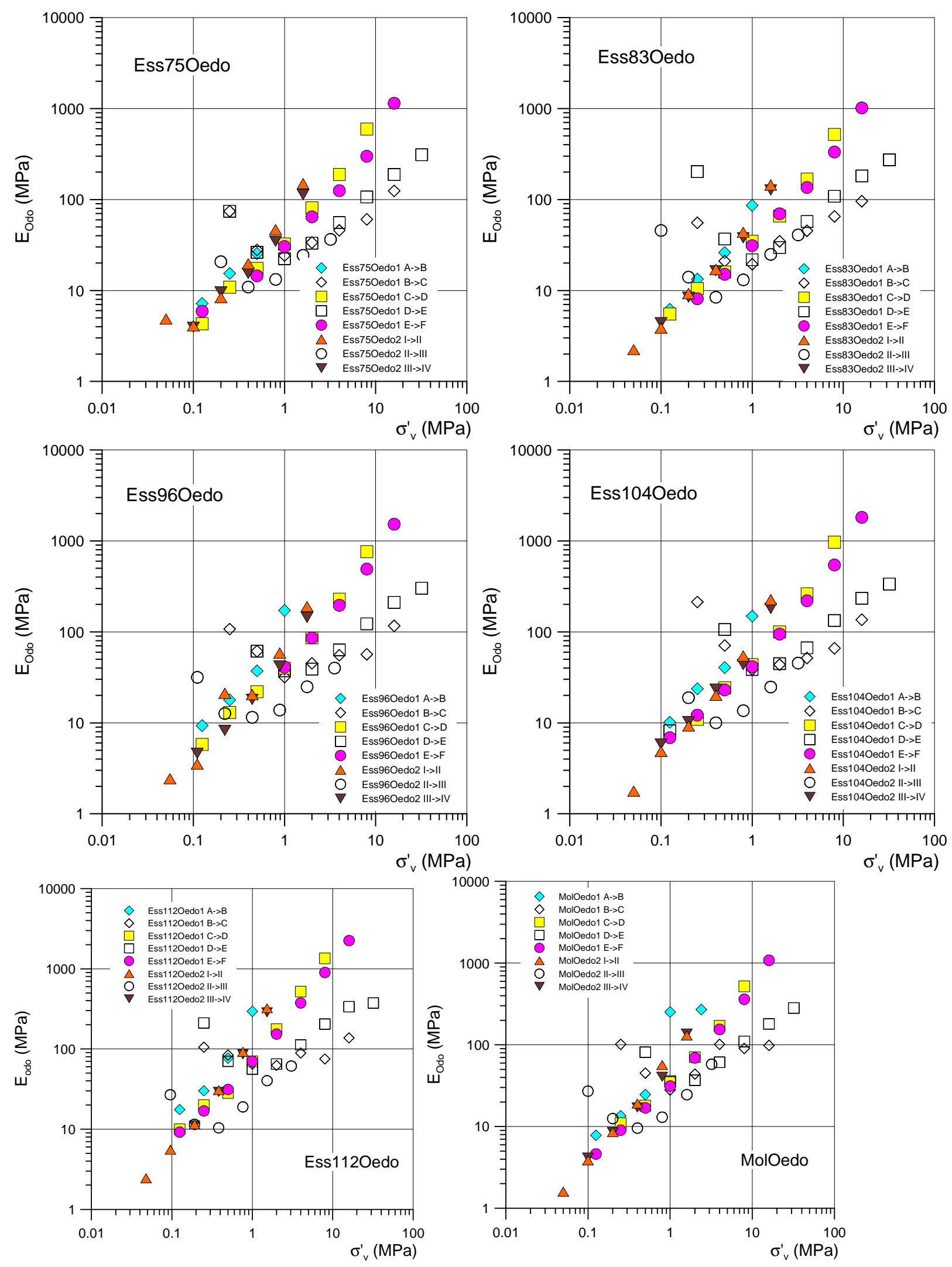

Figure 9. Oedometer modulus versus vertical effective stress 

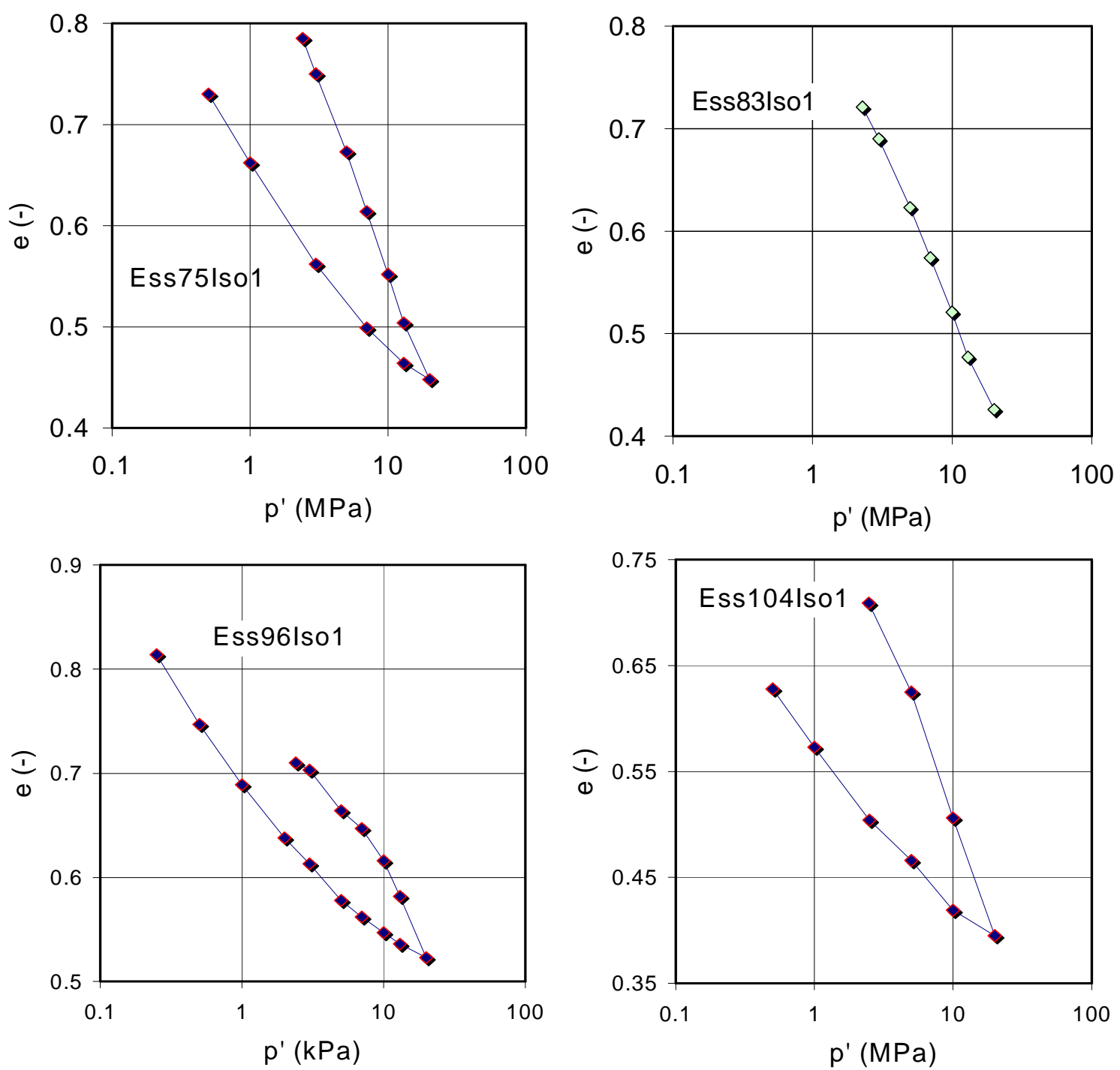

Figure 10. Compression curves from isotropic consolidation tests 

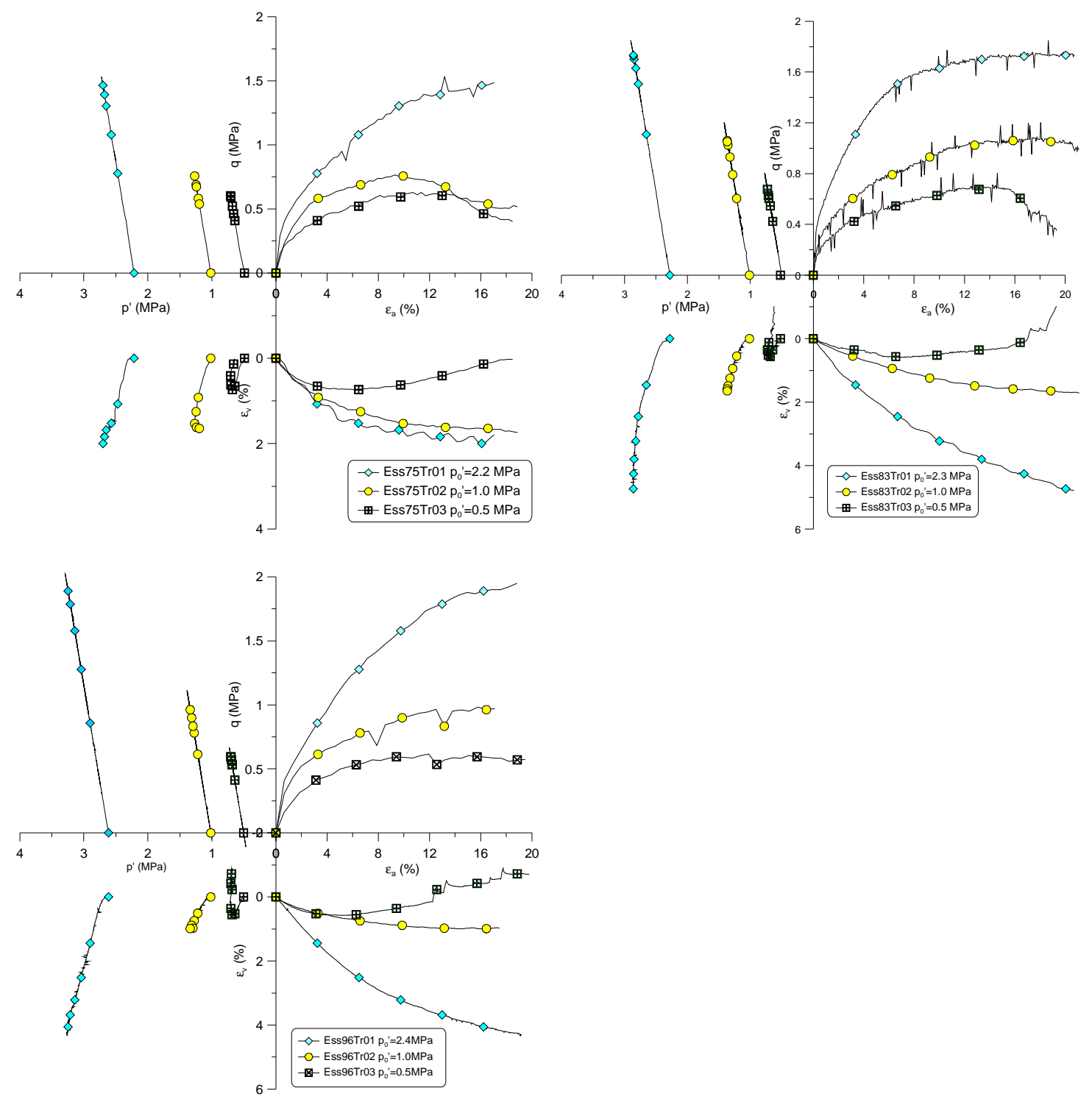

Figure 11. Results from triaxial shear tests on Ess75, Ess83 and Ess96 

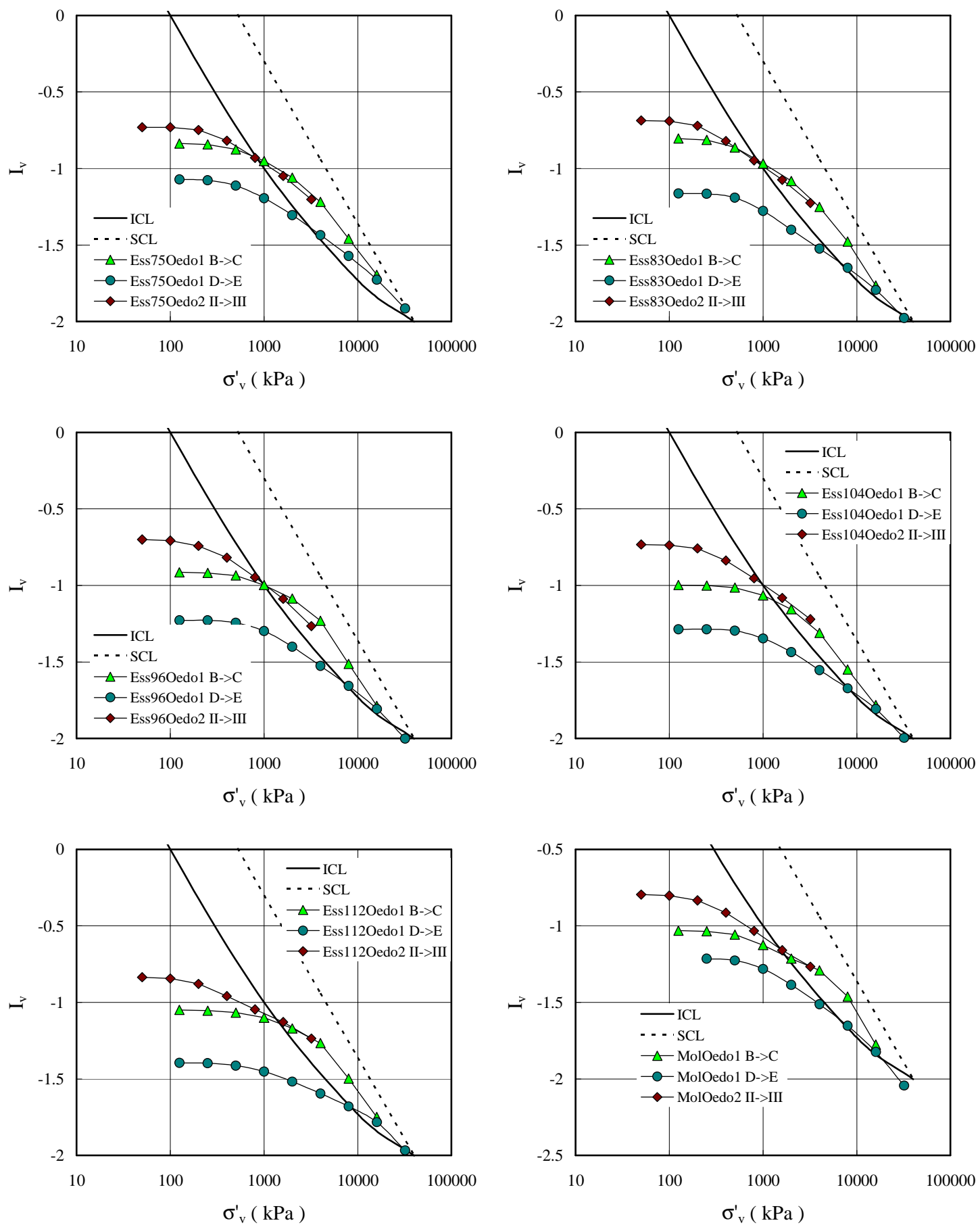

Figure 12. $I_{v}-\sigma^{\prime}{ }_{v}$ curves for Boom clay at Essen and Mol 


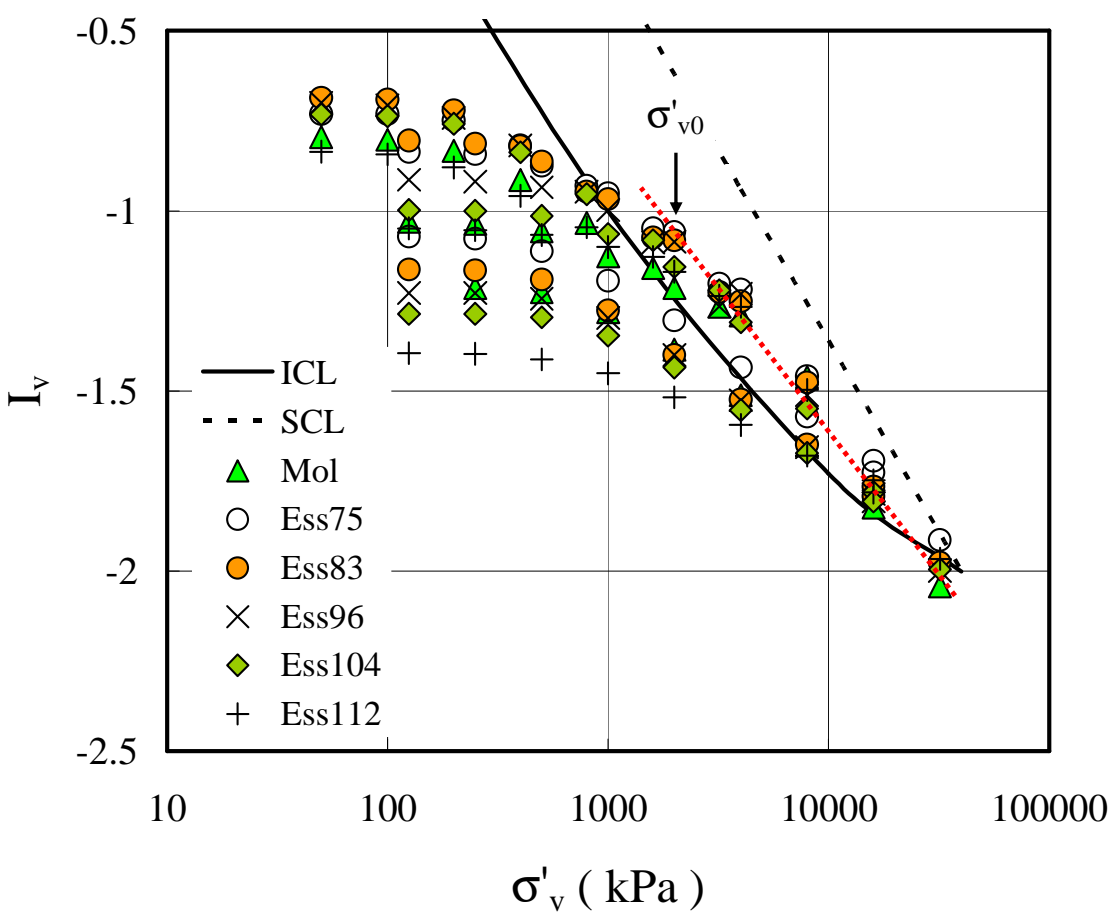

Figure 13. $I_{v}-\sigma^{\prime}{ }_{v}$ curves for all cores studied 


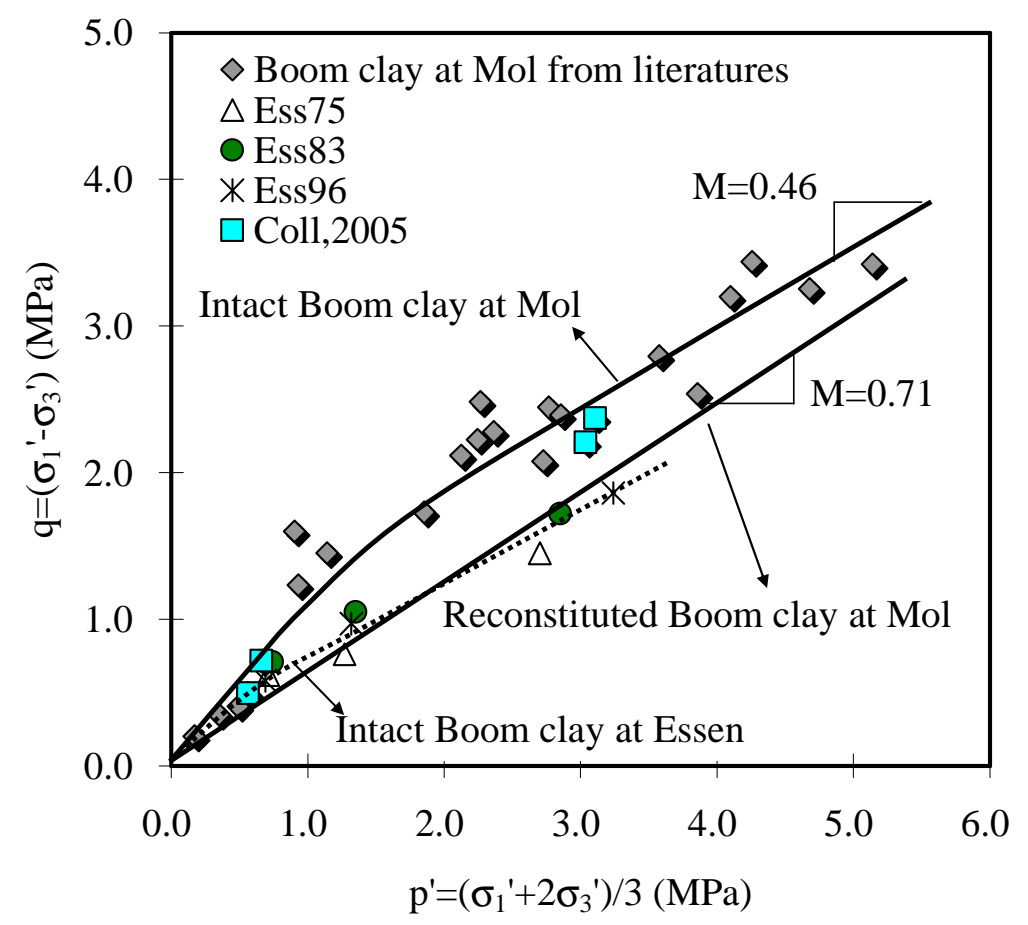

Figure 14. Failure envelopes in $p^{\prime}-q$ plane for intact and reconstituted Boom clay at Mol, and intact Boom clay at Essen 


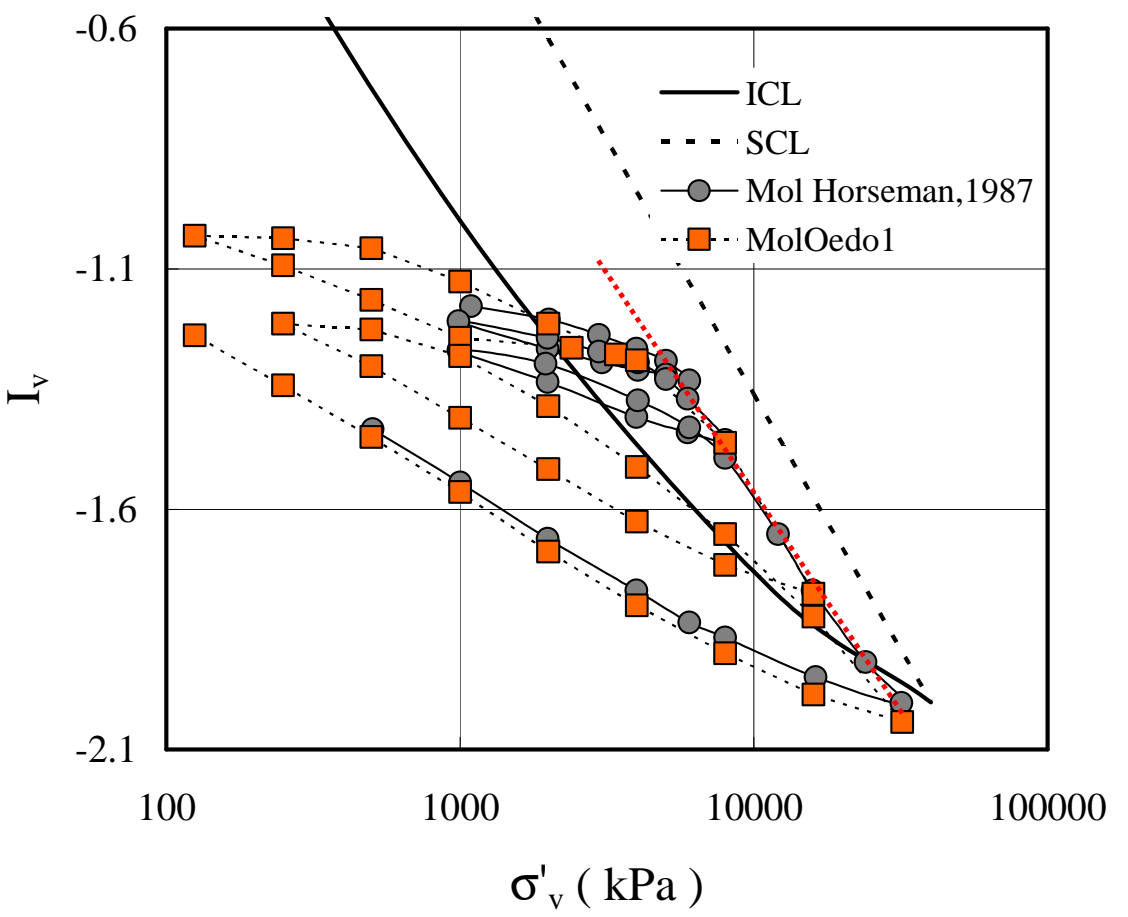

Figure 15. $I_{v}-\sigma_{v}^{\prime}$ curves for Boom clay at Mol 